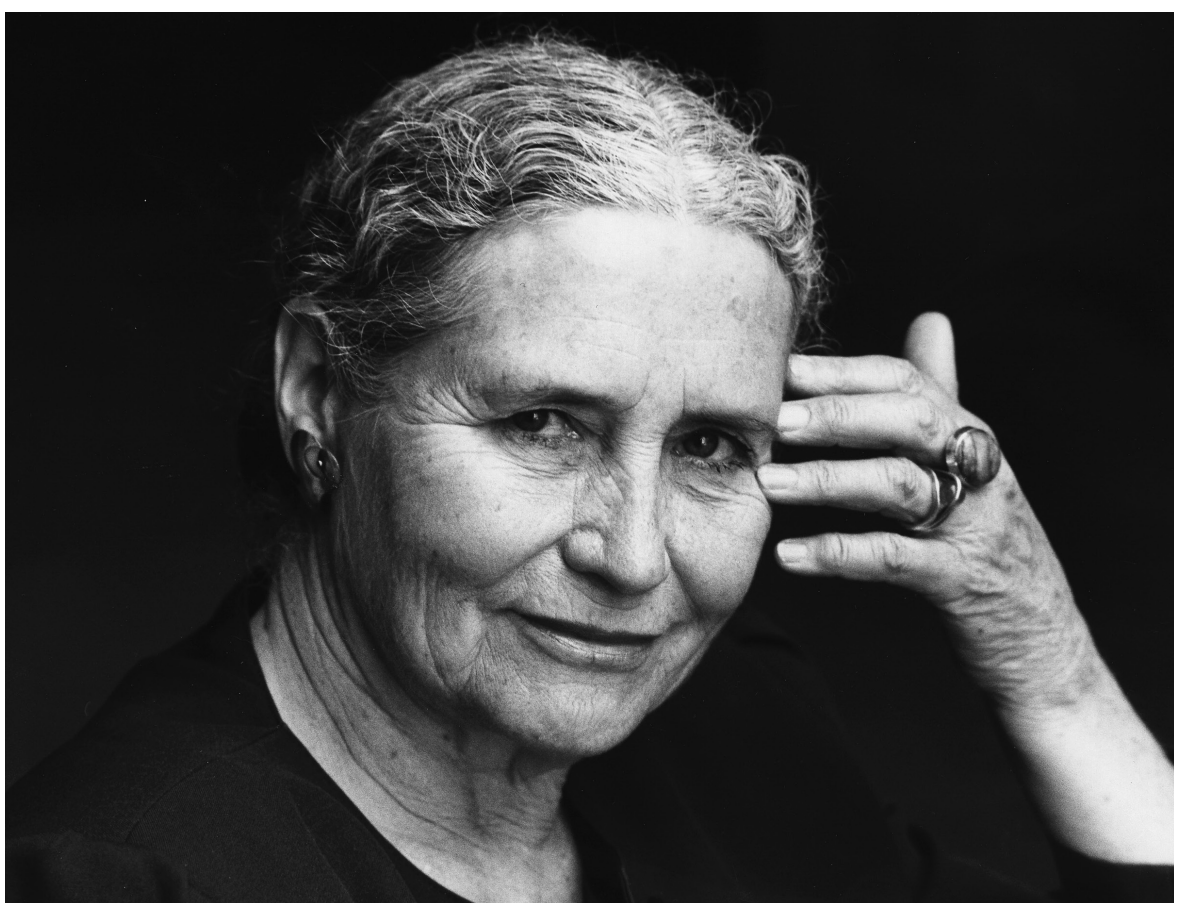

Doris Lessing, photographed in 1990.

FICTION

\section{Doris Lessing at 100: roving time and space}

\section{On the Nobel laureate's centenary, Patrick French explores her science-infused series Canopus in Argos.}

$\mathrm{I}$ $\mathrm{n}$ the 1920s, growing up on a poor farm in Southern Rhodesia (now Zimbabwe) Doris Lessing received impromptu outdoor lessons in space science from her mother, Emily. "Stones stood for Pluto, for Mars. I was Mercury and my brother Venus, running around my father, while she was the earth, moving slowly," she wrote.

Lessing wove space exploration, migration, climate change and social disintegration into novels that seem astonishingly prescient today. Leaving Africa for London in 1949, the fierce intelligence and impulsive curiosity of this driven autodidact led her into literary investigations of subjects as varied as genetics, nuclear warfare and post-colonialism. She wrote more than 60 books between 1950 and her death in 2013 at the age of 94 . Six years before she died, she won the Nobel Prize in Literature - the first, and so far only, British woman to do so.

Her lifelong interest in science and societal upheaval is embodied in fascinating ways in Canopus in Argos, a series of five books published from 1979 to 1983. (She came up with the title a few weeks after seeing, and loving, George Lucas's film Star
Wars, in 1978. The inspiration might have been the 'crawl text' at the film's start.)

Lessing intended the first book, Shikasta, to break the bounds of her earlier work. She wanted to write open-ended space fiction as a study of social systems, taking in colonial dominance, sexuality and gender, evolution, eschatology and ideas about memory and power. She was not very interested in the mechanics of science fiction: a character might be "space-lifted" to another planet with little explanation. But in her futuristic anthropological analysis, much else of sci-fi culture is recognizable. She had been writing psychedelic, semi-realist fiction a decade before: The Four-Gated City (1969) ends in plague and the outbreak of the Third World War.

Today, as I research Lessing's authorized biography, I rarely find readers who appreciate both the space-based and the earthbound books. Admirers of the Canopus series, who tend to be younger and from a scientific background, usually have little interest in the rest of her work. And I have heard literary fans of The Golden Notebook (1962) declare in pained terms how much they resent her wilful shift to sci-fi.
Shikasta presents a revised version of Earth in the titular planet. Reports written by colonial servants of the galactic empire Canopus, historical texts, accounts and case studies create a diffuse narrative. There are echoes of Southern Rhodesia, where white settlers had seeded themselves at the end of the nineteenth century: Lessing described it as "a very nasty little police state". For instance, native people on Rohanda (a colony that reappears in the more sociological third book, The Sirian Experiments) are subjected to "an all-out booster, Top-Level Priority, Forced-Growth Plan", an explicit imperialist project. The second book, The Marriages Between Zones Three, Four and Five, set in 'zones' of civilization circling Shikasta, is an intense and explosive exploration of gender dynamics and stereotypical interactions between men and women.

In The Making of the Representative for Planet 8, Lessing examines human behaviour in the face of a brutal ice age. The inhabitants of Planet 8 must ultimately accept climatebased extinction, aided by a Canopean official, Doeg. This mythic apocalyptic parable was influenced by Anna Kavan's 1967 sci-fi novel Ice, as well as the death of British explorer Robert Falcon Scott in Antarctica in 1912, which fascinated Lessing. Towards the end, echoing current perceptions of planetary fragility, an inhabitant notes that "what we were seeing now with our new eyes was that all the planet had become a fine frail web or lattice, with the spaces held there between the patterns of the atoms".

The last book, The Sentimental Agents in the Volyen Empire, is a tonal shift: a farcical study of imperialism or, as Lessing asserted, "old-fashioned satire in space fiction terms".

\section{BITING BACK}

Lessing wrote the five books at typically breakneck speed. Initially, they were greeted with bafflement. Novelist Anthony Burgess, author of the dystopian novel A Clockwork Orange (1962), complained of her "fanciful cosmic viewpoint". Although science-fiction doyenne Ursula K. Le Guin praised some character sketches in Shikasta as "immortal diamond", she found the whole at times "little more than a pulp-Galactic Empire with the Goodies fighting the Baddies".

Undeterred, Lessing worked her way through the series, declaring bloodymindedly that "space fiction, with science fiction, makes up the most original branch of literature now". She had friends among sci-fi authors, including Brian Aldiss, and happily attended meetings of the International Conference on the Fantastic in the Arts. She championed the genre as influential in mainstream literature, whose pundits nevertheless "are much to blame for patronising or ignoring it". The critical readings became more analytical by 1982, when she published The Making of the Representative for Planet 8 , 
the series' most moving book.

Canopus in Argos also offered Lessing a way to address her own past, present and alternative futures. She had long presumed that a nuclear bomb was likely to fall on Europe, and that the planet faced annihilation. In 1957, she was present at the formation of the Campaign for Nuclear Disarmament. She believed in extraterrestrial intelligent life, and collected information on NASA plans for a 'man-in-a-can' hybrid spacecraft and rover; a 'complete defence shelter system' for nuclear attacks made by German company Thyssen; and schematics of space colonies and ventilation systems prepared for NASA's space scientists.

\section{SPACE FLIGHT}

Her interest in space persisted. In the 1980s, she wrote the libretti for US composer Philip Glass's grand operatic adaptation of The Making of the Representative for Planet 8 (she collaborated again with him on his 1997 opera The Marriages Between Zones Three, Four, and Five). In 1988, Glass arranged a visit to NASA's spaceflight centre in Houston, Texas, where she toured a model of the first US space station, Skylab, with John Frassanito, who had helped to design its interiors.

When a respected novelist veers off on a new path, critics will seek to find the intellectual rationale. They see it as a set of deliberate choices, and this interpretation can be stoked by the writer offering confident justifications in interviews, as Lessing did for Canopus in Argos. The biographer, by contrast, tends to search for proximate personal causes, tying the shift to moments of psychological importance for the writer.

And with Lessing, the biographical aspect is important. For instance, along with her interest in scientific fields from physics to neurology, she shared and influenced the counter-cultural mood prevailing among young people in the 1960s. By the late 1970s this became doom-laden, in response to environmental threats such as toxic waste. Youthful revolt over planetary destruction permeates Shikasta in particular.

Yet Lessing resisted classification. Her speculative space fiction was part of an unusual creative journey. Her next two novels turned from space back to Earth, and youth to age. Written under the pseudonym Jane Somers, they pivoted on the state of elderhood - which now, on our greying planet, has become another burgeoning field of study.

Patrick French is dean of the School of Arts and Sciences and professor for the public understanding of the humanities at Ahmedabad University in India. He is the authorized biographer of Doris Lessing. His books include The World Is What It Is: The Authorized Biography of V.S. Naipaul. e-mail:prbfrench@gmail.com

\section{Books in brief}

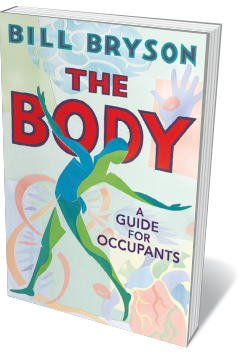

The Body

Bill Bryson DOUBLEDAY (2019)

From skin to gut, the human body is a realm of wonder, and Bill Bryson's tome explores it to its thrumming depths. The book bristles with data such as our allotment of cells (37.2 trillion) or daily faeces production (200 grams), but the star turns are Bryson's wry forays into the histories of neuroscience, genetics, anatomy and immunology. Cue visceral gems such as diarist Samuel Pepys's gruesome bladder-stone surgery, and US physician Chevalier Quixote Jackson's retrieval of thousands of ingested items (including miniature binoculars and a poker chip) over his 75-year career.

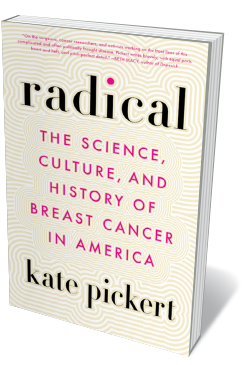

Radical

Kate Pickert LITTLE, BROWN SPARK (2019)

Part of Kate Pickert's beat as a health-care journalist was breast cancer. In 2014, she became one of 300,000 US women diagnosed with the condition that year, and set out to recontextualize its convoluted history. She probes the brutal legacy of controversial mastectomy pioneer William Halsted, the discovery of cancer drug Taxol (paclitaxel) and debates over screening. She tours pharmaceuticals giant Genentech, interviews researchers such as Dennis Slamon and sits in on breast-reconstruction surgery. And she recounts her own medical journey with impressive aplomb. Balanced, cogent and eye-opening.

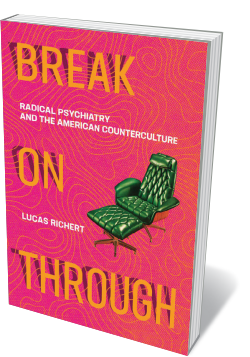

Break on Through

Lucas Richert MIT PRESS (2019)

Sixty years ago, amid socio-economic stresses and cultural convulsions, US psychiatry went through a paradigm shift: radical approaches to therapy, newly approved pharmaceuticals and experimentation with hallucinogens proliferated. In this episodic narrative, historian of pharmacy Lucas Richert picks through the explosive developments alongside the multitude of figures involved, such as psychologist Abraham Maslow, anti-psychiatrist R. D. Laing, ex-patient and activist Judi Chamberlin and researcher Sanford $M$. Unger, who studied the use of LSD in psychotherapy.

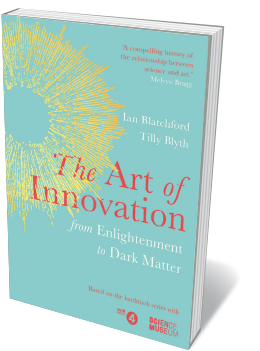

\section{The Art of Innovation}

lan Blatchford and Tilly Blyth BANTAM (2019)

This fascinating compilation of 20 "brief yet rich" historical moments when art and science commingled draws on a BBC Radio 4 series by lan Blatchford and Tilly Blyth. Director and principal curator at London's Science Museum, respectively, they gaze back over 250 years of crossover creativity. Here are landscape painter John Constable "skying" in the 1820s, painting cloudscapes and jotting down meteorological data; the mind-boggling motion photography of Eadweard Muybridge and Étienne-Jules Marey; and the mathematical models that inspired sculptor Barbara Hepworth.

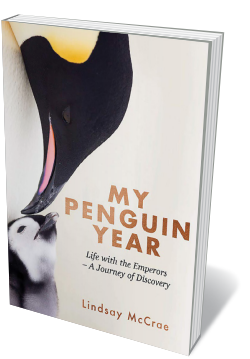

\section{My Penguin Year}

Lindsay McCrae HODDER \& STOUGHTON (2019)

In December 2016, Lindsay McCrae set out for Antarctica as director of photography for the BBC television series Dynasties, narrated by David Attenborough. Amid ice, whales, petrels, seals and vast shoals of fish, McCrae followed thousands of emperor penguins (Aptenodytes forsteri) for nearly a year. His remarkable memoir is rich in the technological and logistical challenges of filming in extreme conditions. But most gripping are his fine-tuned observations of these beautiful metre-high birds, which must survive and raise their young in temperatures as low as $-60^{\circ} \mathrm{C}$. Barbara Kiser 